\title{
STUDI PROSPEKTIF POTENSI INTERAKSI OBAT GOLONGAN ANTIBIOTIK PADA PASIEN PEDIATRI DI RUMAH SAKIT ANANDA PURWOKERTO
}

\section{PROSPECTIVE STUDY OF POTENTIAL INTERACTIONS OF ANTIBIOTICS IN PEDIATRIC PATIENTS AT ANANDA PURWOKERTO HOSPITAL}

\author{
Much Ilham Novalisa Aji Wibowo, Rima Anggita Pratiwi, Elza Sundhani \\ Faculty of Pharmacy, Universitas Muhammadiyah Purwokerto, \\ Jl. Raya Dukuhwaluh, Dukuhwaluh, Kembaran, Purwokerto 53182, Indonesia \\ Email: aji.wibowo.ump@gmail.com (Much Ilham Novalisa Aji WIbowo)
}

\begin{abstract}
ABSTRAK
Interaksi obat terjadi pada saat efek suatu obat (index drug) berubah akibat adanya suatu interaksi dengan obat lain (precipitant drug), makanan, atau minuman. Perubahan ini dapat berinteraksi menghasilkan efek yang dikehendaki (Desirable Drug Interaction), atau efek sebaliknya yaitu tidak dikehendaki (Adverse Drug Interaction). Dilaporkan bahwa kejadian interaksi obat lebih banyak terjadi pada pasien dewasa, sedangkan laporan mengenai kejadian interaksi obat pada pasien anak masih sedikit. Penelitian ini bertujuan untuk mengetahui potensi interaksi obat golongan antibiotik yang terjadi pada resep pasien pediatri di Rumah Sakit Ananda, Purwokerto. Penelitian dilakukan secara deskriptif noneksperimental dengan pengambilan data prospektif dilakukan pada data rekam medik dan resep pasien pediatri pada bulan Februari - April 2018. Sampel diperoleh secara purposive sampling dengan kriteria inklusi pasien pediatri yang tergolong bayi (usia 28 hari-23 bulan), anak-anak (usia 2-11 tahun), dan remaja (usia 12-18 tahun), pasien pediatri yang mendapat resep obat yang mengandung antibiotik, pasien pediatri yang mendapat obat $\geq 2$ macam obat secara bersamaan, pasien pediatri yang dirawat di Instalasi Rawat Inap Rumah Sakit Ananda Purwokerto. Hasil penelitian menunjukkan terdapat 11 kasus kombinasi obat yang diidentifikasi berpotensi menyebabkan interaksi obat. Jenis interaksi obat terjadi pada interaksi farmakokinetik $(54,5 \%)$ dan farmakodinamik (45,5\%). Potensi interaksi antibiotik dengan antibiotik maupun dengan obat lain terjadi pada kategori mayor $(18,2 \%)$, moderat $(72,7 \%)$, dan minor $(9,1 \%)$. Kesimpulan penelitian yaitu terdapat interaksi antara antibiotik dengan antibiotik maupun dengan obat lain. Interaksi obat terjadi pada fase farmakokinetik dan farmakodinamik. Tingkat keparahan interaksi yang terjadi yaitu mayor, moderat, dan minor.
\end{abstract}

Kata kunci: antibiotic, interaksi obat, pediatrik, rumah sakit. 


\begin{abstract}
Drug interactions occur when the effect of a drug is changed due to an interaction with other drugs, foods, or drinks. This change can produce the desired effect (Desirable Drug Interaction) or undesired ones (Adverse Drug Interaction). It is reported that the incidence of drug interactions is more common in adult patients, while those in pediatric patients are less reported. This study aims to determine the potential drug interactions occurring in pediatric patients prescribed with antibiotics in Ananda Hospital Purwokerto. It is a nonexperimental descriptive study with prospective data collection and is subjected to the medical record and prescription of pediatric patients in February April 2018. Samples were obtained by purposive sampling with inclusion criteria as follow: pediatric patients including infants (28 days-23 months old), children (2-11 years old), and adolescents (12-18 years old), received prescribtion containing antibiotics, prescribed with $\geq 2$ types of drugs simultaneously, and hospitalized in Ananda Hospital Purwokerto. The results showed there were 11 cases of drug combinations identified as potentially causing drug interactions. Types of drug interactions were pharmacokinetic (54.5\%) and pharmacodynamics (45.5\%) interactions. Potential antibiotic-antibiotic interactions as well as interactions with other drugs could be categorized into the major (18.2\%), moderate (72.7\%), and minor (9.1\%) categories. It can be concluded there was interactions between antibiotics with antibiotics and also with other drugs, that occurred in the pharmacokinetic and pharmacodynamic phases. The severity of those interactions were in major, moderate, and minor category.
\end{abstract}

Key words: antibiotics, drug interactions, hospitals, paediatrics. 


\section{Pendahuluan}

Interaksi obat terjadi pada saat efek suatu obat (index drug) berubah akibat adanya suatu interaksi dengan obat lain (precipitant drug), makanan, atau minuman. Perubahan ini dapat berinteraksi menghasilkan efek yang dikehendaki (Desirable Drug Interaction), atau efek sebaliknya yaitu tidak dikehendaki (Adverse Drug Interaction) (Ament et al., 2000).

Potensi terjadinya interaksi obat dalam suatu resep obat masih sering terjadi di seluruh dunia termasuk Indonesia. Bahkan dilaporkan dalam penelitian di Amerika, terjadi kejadian interaksi obat di rumah sakit sebesar 7,3 dan $88 \%$ di antaranya terjadi pada kelompok pasien khusus (geriatri) (Juurlink et al., 2003). Dilaporkan bahwa kejadian interaksi obat banyak terjadi pada pasien dewasa, tetapi laporan mengenai kejadian interaksi obat pada pasien anak masih sedikit (Sjahadat dan Muthmainah, 2013).

Suatu survei mengenai insiden efek samping penderita rawat inap yang menerima 5 macam obat adalah 3,5\%, sedangkan yang mendapat 16-20 macam obat menderita efek samping sebesar 54\%. Peningkatan kejadian efek samping melebihi peningkatan jumlah obat diperkirakan akibat terjadinya interaksi obat (Setiawati, 1995). Kemudian menurut penelitian Farida dan Soleqah (2016) di RSUD Dr. Moewardi Surakarta menunjukkan bahwa pada peresepan 64 pasien pneumonia dengan penyakit penyerta, ditemukan 12 jenis obat yang berpotensi berinteraksi dengan antibiotik. Potensi interaksi antibiotik dengan obat lain berdasarkan literatur terjadi pada fase absorbsi (12,82\%), metabolisme (35,9\%), dan ekskresi (51,28\%). Profil keamanan suatu obat baru didapatkan setelah obat tersebut sudah diedarkan dan digunakan secara luas di masyarakat, termasuk oleh populasi pasien yang sebelumnya tidak terwakili dalam uji klinik obat tersebut, salah satunya adalah anak-anak. Konsekuensinya, diperlukan beberapa bulan atau bahkan tahun sebelum diperoleh data yang memadai tentang masalah efek samping akibat interaksi obat.

Berdasarkan masalah tersebut maka diperlukan suatu studi untuk mengidentifikasi potensi interaksi obat antibiotik dengan semua obat yang diresepkan kepada pasien pediatri di Rumah Sakit Ananda Purwokerto. Dengan mengetahui potensi interaksi, 
mekanisme interaksi obat, dan tingkat keparahan interaksi obat antibiotik yang terjadi pada resep pasien pediatri, dapat diperkirakan kemungkinan resiko yang dihadapi serta penanganannya.

\section{Metode Penelitian}

Sampel Penelitian

Studi ini merupakan penelitian survei noneksperimental menggunakan metode survei deskriptif dan teknik pengambilan data dilakukan secara prospektif. Peneliti melakukan follow up data-data primer yang didapat dari rekam medis sesaat setelah visite dokter di ruangan pada periode Februari-April 2018. Jumlah sampel adalah 100 data peresepan. Sampel penelitian diambil secara purposive sampling dengan beberapa pertimbangan kriteria inklusi yaitu:

1. Pasien pediatri dari dokter umum, dokter spesialis anak, atau dokter spesialis lain yang tergolong bayi (usia 28 hari-23 bulan), anak-anak (usia 2 11 tahun), dan remaja (usia 12-18 tahun) sesuai The International Commite on Harmonization (2015).

2. Pasien pediatri yang mendapat resep obat yang mengandung antibiotik.
3. Pasien pediatri yang mendapat obat $\geq 2$ jenis obat (antibiotik dan/atau nonantibiotik) secara bersamaan.

4. Pasien pediatri yang dirawat di Instalasi Rawat Inap Rumah Sakit Ananda, Purwokerto.

Sedangkan kriteria eksklusi yang digunakan meliputi pasien pediatri dalam perawatan gawat darurat dan ICU.

Alat dan Bahan

Alat dan bahan yang digunakan dalam penelitian ini antara lain rekam medik pasien, resep obat, lembar pengumpulan data pasien, dan aplikasi android drugs.com. Data yang diperoleh diolah secara deskriptif yang digunakan untuk melaporkan hasil dalam bentuk distribusi frekuensi dan persentase (\%).

\section{Hasil dan Pembahasan}

Karakteristik Pasien Berdasarkan Jenis Kelamin

Berdasarkan hasil pengolahan data 100 pasien pediatri yang mendapat resep antibiotik (Tabel 1), terdapat jumlah pasien pediatrik perempuan lebih banyak daripada laki-laki yaitu 52 pasien (52\%). Menurut Rahayuningsih dan Mulyadi (2017), perempuan cenderung memiliki kondisi fisik yang lebih lemah dari laki-laki, hal ini berkorelasi dengan 
Tabel 1. Karakteristik pasien

\begin{tabular}{lcc}
\hline \multicolumn{1}{c}{ Variabel } & $\Sigma$ & $\mathbf{( \% )}$ \\
\hline A. Jenis Kelamin & & \\
1. Laki - laki & 48 & 48 \\
2. Perempuan & 52 & 52 \\
B. Usia & & \\
1. Bayi (28 hari-23 bulan) & 34 & 34 \\
2. Anak-anak (2-11 tahun) & 45 & 45 \\
3. Remaja (12-18 tahun) & 21 & 21 \\
C. Diagnosa Penyakit & & \\
1. Bronkitis & 12 & 10,71 \\
2. Bronkopneumonia & 11 & 9,82 \\
3. Demam Tifoid & 15 & 13,39 \\
4. DADS (Diare Akut Dehidrasi Sedang) & 10 & 8,93 \\
5. Febris & 36 & 32,14 \\
6. GEA (Gastroenteritis Akut) & 8 & 7,14 \\
7. ISPA (Infeksi Saluran Pernapasan Akut) & 9 & 8,04 \\
8. Kejang Demam & 5 & 4,46 \\
9. Post Apendiktomi & 3 & 2,68 \\
10. Tuberkulosis & 3 & 2,68 \\
\hline
\end{tabular}

\section{Karakteristik Pasien Berdasarkan Usia}

Pasien pediatri yang mendapat resep obat antibiotik tertinggi pada pasien pediatri kelompok anak-anak usia 2-11 tahun sebanyak 45 pasien (45\%). Bayi dan anak-anak merupakan kelompok usia yang memiliki sistem kekebalan tubuh yang belum sempurna dibandingkan dengan orang dewasa sehingga kelompok usia ini lebih rentan terinfeksi bakteri dan berbagai sumber penyakit lainnya (Ramadhan et al., 2015). Pasien pediatri yang mendapat resep obat antibiotik paling sedikit adalah pasien pediatri kelompok usia remaja usia 12-18 tahun sebanyak 21 (21\%). Hal ini dikarenakan sistem imunitas pada usia remaja masih baik dibandingkan umur dewasa tua, anak, dan usia lanjut (Ramadhan et al., 2015).

Karakteristik Pasien Berdasarkan Diagnosa Penyakit

Terdapat 10 diagnosa penyakit tertinggi yang diderita oleh pasien pediatri yang dirawat inap di Rumah Sakit Ananda, Purwokerto (Tabel 1). Diagnosa penyakit tertinggi yaitu febris sebanyak 36 pasien (32,14\%). Demam 
merupakan salah satu manifestasi yang umum terjadi pada anak (Hartini dan Pertiwi, 2015). Indikasi febris dibutuhkan antibiotik dikarenakan data leukosit meningkat dan suhu di atas rata-rata. Demam yang terjadi karena infeksi virus akan sembuh dalam beberapa hari, sedangkan demam yang disebabkan karena infeksi bakteri berdurasi lebih dari 3 hari dan kondisi tubuh anak akan lemah (Maharani et al., 2017).

Karakteristik Resep Berdasarkan Jumlah dan Jenis Obat

Karakteristik pasien

menunjukkan jumlah jenis obat $\geq 5$ lebih banyak dari pada jumlah jenis obat 2 hingga <5 yakni sebanyak 88 lembar (88\%) (Tabel 2). Pasien pediatri yang dirawat inap mendapat resep obat dengan jumlah jenis obat $\geq 5$ dikarenakan beberapa pasien memiliki diagnosis penyakit lebih dari satu dan beberapa pasien mendapat terapi antibiotik kombinasi seperti pada pasien TB paru sehingga pasien tersebut membutuhkan pengobatan yang lebih banyak. Menurut Rikomah (2016), kemungkinan terjadinya interaksi obat akan semakin besar dengan meningkatnya kompleksitas obat-obat yang digunakan dalam pengobatan.

Tabel 2. Karakteristik resep

\begin{tabular}{lcc}
\hline \multicolumn{1}{c}{ Variabel } & $\Sigma$ & (\%) \\
\hline A. Jumlah \& Jenis Obat & & \\
1. $2-<5$ & 12 & 12 \\
2. $\geq 5$ & 88 & 88 \\
B. Jenis Antibiotik & & \\
1. Ampisilin & 16 & 14,81 \\
2. Cefixime & 12 & 11,11 \\
3. Ceftriaxone & 47 & 43,52 \\
4. Cefotaxime & 27 & 25,00 \\
5. Gentamisin & 6 & 5,56 \\
\hline
\end{tabular}

\section{Karakteristik Antibiotik pada Resep Pasien Pediatri}

Terdapat 5 jenis antibiotik yang digunakan oleh pasien pediatri (Tabel 2). Antibiotik yang banyak digunakan oleh pasien pediatri yaitu ceftriaxone sebanyak 47 pasien (43,52\%). Ceftriaxone merupakan golongan sefalosporin generasi ke-3 yang umum dan banyak digunakan karena mempunyai potensi antibakteri yang 
tinggi, dan memiliki potensi toksisitas yang rendah. Jenis antibiotik tersebut memiliki spektrum yang luas sehingga dapat mengatasi dengan baik pada bakteri gram positif maupun gram negatif dan beberapa bakteri anaerob lain termasuk Streptococcus pneumoniae, Haemophilus influenzae, dan Pseudomonas (Sinaga et al., 2017). Antibiotik ini juga lebih tahan terhadap resistensi laktamase, tetapi khasiatnya terhadap staphylococcus lebih rendah (Tjay dan Rahardja, 2015).

Potensi Interaksi Obat pada Resep Pasien Pediatri

Berdasarkan studi literatur identifikasi interaksi obat pada 100 resep pasien pediatri didapatkan sebanyak 55
(55\%) resep pasien pediatri yang mengalami interaksi obat (Tabel 3). Adapun literatur yang digunakan antara lain aplikasi drugs.com tahun 2018, Stockley's Drug Interaction (Baxter, 2010), Drug Interaction Facts (Tatro, 2008), dan Drug Information Handbook tahun 2009 (Aberg et al., 2009). Interaksi obat dianggap penting secara klinis jika berakibat meningkatkan toksisitas dan/atau mengurangi efektivitas obat yang berinteraksi, terutama jika menyangkut obat dengan batas keamanan yang sempit (indeks terapi sempit) misalnya glikosida jantung, antikoagulan, dan obat-obat sitostatik (Rikomah, 2016).

Tabel 3. Potensi interaksi obat pada resep pasien pediatri

\begin{tabular}{|c|c|c|c|}
\hline Potensi Interaksi Obat & & $\Sigma$ & (\%) \\
\hline Ada Interaksi Obat & & 55 & 55 \\
\hline Tidak Ada Interaksi Obat & & 45 & 45 \\
\hline & Total & 100 & 100 \\
\hline
\end{tabular}

\section{Potensi Interaksi Obat Berdasarkan} Jumlah Jenis Obat

Berdasarkan data pada Tabel 4, dapat diketahui potensi interaksi obat lebih banyak terjadi pada lembar resep dengan jumlah obat $\geq 5$ yaitu sebanyak 55 lembar resep (62,5\%). Hal ini sejalan dengan penelitian Utami (2013) yang menunjukkan bahwa kejadian interaksi obat lebih banyak terjadi pada pasien yang menerima $\geq 5$ macam obat dibandingkan dengan pasien yang menerima $<5$ macam obat. Keadaan ini dapat terjadi pada pasien rawat jalan 
dan rawat inap yang ditandai dengan adanya kejadian efek samping maupun perubahan khasiat akibat terapi kombinasi obat (Chelkeba et al., 2011). Peresepan obat pada pasien anak yang berisikan banyaknya macam obat dalam satu resep memungkinkan terjadinya polifarmasi yang kemudian akan berpotensi terjadi interaksi obat (Rambhade et al., 2012). Polifarmasi bisa sangat merugikan pada anak-anak karena kondisi fisiologis mereka yang terbatas (Getachew et al., 2016).

Tabel 4. Potensi interaksi obat berdasarkan jumlah jenis obat

\begin{tabular}{ccccc}
\hline ¿ Jenis Obat & & Interaksi & Tidak berinteraksi & $\Sigma$ \\
\hline $2-<5$ & $\mathrm{~N}$ & 0 & 12 & 12 \\
& $\%$ & $0 \%$ & $100 \%$ & $100 \%$ \\
$\geq 5$ & $\mathrm{~N}$ & 55 & 33 & 88 \\
& $\%$ & $62,5 \%$ & $37,5 \%$ & $100 \%$ \\
& $\mathrm{~N}$ & 55 & 45 & 100 \\
Total & $\%$ & $55 \%$ & $45 \%$ & $100 \%$ \\
\hline
\end{tabular}

Penggunaan Antibiotik yang Berpotensi Memiliki Interaksi Obat

Tabel 5 menunjukkan hasil analisis dari 55 resep pasien pediatri yang mengalami interaksi obat. Terdapat 11 kasus interaksi antibiotik-antibiotik maupun dengan obat lain jika diberikan secara bersamaan. Potensi interaksi obat golongan antibiotik banyak terjadi pada interaksi antara ampisilin dan gentamisin sebanyak 5 kasus $(45,5 \%)$. Kombinasi kedua obat tersebut dapat memberikan efek yang sinergis karena dapat meningkatkan efek bakterisida. Namun jika diberikan sekaligus, kedua antibiotika tersebut akan bersifat antagonis (Almasdy et al., 2013). Rifampisin dan isoniazid merupakan induktor kuat enzim pada sistem isoenzim sitokrom P-450 sehingga dapat mengakibatkan penurunan konsentrasi obat-obat yang dimetabolisme oleh sistem isoenzim tersebut (Sukandar dan Hartini, 2012). 
Vol.15 No. 02 Desember 2018

Tabel 5. Penggunaan antibiotik yang berpotensi memiliki interaksi obat

\begin{tabular}{|c|c|c|c|c|c|}
\hline Interaksi Obat & $\begin{array}{c}\text { Tingkat } \\
\text { Keparahan }\end{array}$ & $\begin{array}{c}\text { Pola } \\
\text { Mekanisme }\end{array}$ & $\begin{array}{c}\text { Fase Interaksi } \\
\text { Obat }\end{array}$ & Jumlah & $\begin{array}{c}\text { Persentase } \\
(\%)\end{array}$ \\
\hline $\begin{array}{l}\text { Ampisilin dan } \\
\text { Gentamisin }\end{array}$ & Moderat & Farmakodinamik & Sinergis & 5 & 45,5 \\
\hline $\begin{array}{l}\text { Isoniazid dan } \\
\text { Parasetamol }\end{array}$ & Mayor & Farmakokinetika & Metabolisme & 2 & 18,2 \\
\hline $\begin{array}{l}\text { Rifampisin dan } \\
\text { Parasetamol }\end{array}$ & Moderat & Farmakokinetika & Metabolisme & 2 & 18,2 \\
\hline $\begin{array}{l}\text { Isoniazid dan } \\
\text { Metilprednisolon }\end{array}$ & Minor & Farmakokinetika & Metabolisme & 1 & 9,1 \\
\hline \multirow[t]{2}{*}{$\begin{array}{l}\text { Rifampisin dan } \\
\text { Metilprednisolon }\end{array}$} & Moderat & Farmakokinetika & Metabolisme & 1 & 9,1 \\
\hline & & & Total & 11 & 100 \\
\hline
\end{tabular}

Potensi Interaksi Obat Antibiotik Berdasarkan Pola Mekanisme Interaksi Obat

Berdasarkan hasil analisis pola mekanisme interaksi obat (Tabel 6), interaksi obat antibiotik yang paling banyak terjadi yaitu pada mekanisme interaksi farmakokinetik sebanyak 6 kasus (54,5\%). Mekanisme interaksi obat pada fase farmakokinetik, maka salah satu obat (index drug) mempengaruhi proses absorpsi, distribusi, metabolism, atau ekskresi obat kedua (precipitant drug) sehingga kadar plasma kedua obat bisa meningkat atau menurun. Akibat selanjutnya adalah terjadi peningkatan toksisitas atau bahkan penurunan efektifitas obat tersebut (Baxter, 2010). Kemudian mekanisme interaksi obat secara farmakodinamik menunjukkan bahwa obat-obat yang diberikan saling berinteraksi pada sistem reseptor, tempat kerja atau sistem fisiologis yang sama sehingga terjadi efek yang aditif, sinergis (saling memperkuat), dan antagonis (saling menghilangkan) (Chelkeba et al., 2013).

Tabel 6. Potensi interaksi obat antibiotik berdasarkan pola mekanisme interaksi obat

\begin{tabular}{lccc}
\hline Mekanisme Interaksi & Jumlah & (\%) \\
\hline Farmakokinetik & 6 & 54,5 \\
Farmakodinamik & & 5 & 45,5 \\
& Total & 11 & 100 \\
\hline
\end{tabular}


Potensi Interaksi Farmakokinetik Obat Antibiotik

Interaksi obat golongan antibiotik yang ditemukan berinteraksi secara farmakokinetik pada penelitian ini terjadi pada penggunaan obat isoniazid dengan parasetamol serta rifampisin dan parasetamol pada penderita TBC. Interaksi tersebut terjadi pada fase metabolisme yang menyebabkan isoniazid dan rifampisin dapat meningkatkan efek obat parasetamol dengan mempengaruhi metabolisme enzim CYP2E1. Isoniazid dan rifampisin akan menginduksi sitokrom P450 isoenzim CYP2E1 sehingga metabolisme parasetamol menjadi metabolit toksik sehingga menyebabkan meningkatnya hepatotoksisitas (Baxter, 2010).

Interaksi rifampisin dengan metilprednisolon juga termasuk dalam kategori interaksi farmakokinetik. Mekanisme interaksi tersebut terjadi pada fase metabolisme dimana rifampisin akan menginduksi enzim metabolisme CYP450 pada kortikosteroid sehingga dapat mengurangi efektivitas dan bioavailability dari kortikosteroid (Baxter, 2010). Isoniazid dan metilprednisolon juga termasuk jenis interaksi farmakokinetik karena terjadi pada fase metabolisme. Penggunaan isoniazid dan kortikosteroid secara bersamaan akan menyebabkan penurunan konsentrasi serum isoniazid melalui peningkatan asetilasi hepatik atau renal clearance oleh isoniazid (Tatro, 2008).

Potensi Interaksi Farmakodinamik Obat Antibiotik

Interaksi farmakodinamik pada penelitian ini juga ditemukan pada pasien yaitu interaksi antara ampisilin dengan gentamisin. Menurut Baxter (2010) terdapat suatu laporan penemuan klinis yang menunjukkan bahwa penggunaan kombinasi kedua obat tersebut dapat memberikan efek menguntungkan (sinergis), terutama dalam pengobatan infeksi Pseudomonas. Selain itu, pemberian penisilin parenteral tertentu dapat menonaktifkan aminoglikosida tertentu secara in vivo maupun in vitro (drug.com). Secara in vitro, interaksi antara ampisilin dengan aminoglikosida dapat menyebabkan berkurangnya efek aminoglikosida, seperti gentamisin. Hal ini terjadi karena gugus amino pada aminoglikosida dan cincin $\beta$-laktam pada penisilin berinteraksi secara kimia untuk membentuk amida yang tidak aktif secara biologis (drug.com). Interaksi 
tersebut biasa disebut dengan interaksi farmaseutik yang terjadi di luar tubuh sebelum obat diberikan antara obat yang tidak dapat bercampur (inkompatibel). Interaksi ini mengakibatkan inaktivasi obat (Setiawati, 2007).

Tabel 7. Potensi interaksi obat antibiotik berdasarkan tingkat keparahan interaksi obat

\begin{tabular}{lcc}
\hline Tingkat Keparahan & Jumlah & Persentase (\%) \\
\hline Mayor & 2 & 18,2 \\
Moderat & 8 & 72,7 \\
Minor & 1 & 9,1 \\
Total & 11 & $100 \%$ \\
\hline
\end{tabular}

Interaksi obat pada kategori moderat menunjukan efek yang bermakna secara klinis, kombinasi obat ini masih bisa digunakan hanya dalam keadaan khusus dan dengan monitoring ketat dari tenaga kesehatan. Dalam penelitian ini ditemukan pada interaksi antara OAT (Obat Antituberkulosis) rifampisin dengan parasetamol. Monitoring ketat diperlukan pada pasien dan jika terjadi perubahan dalam tes fungsi hati, sebaiknya dipertimbangkan untuk penghentian salah satu atau kedua obat tersebut. Interaksi antara OAT rifampisin dengan metilprednisolon juga termasuk dalam kategori moderat karena interaksi tersebut akan mengurangi efektivitas dan bioavailability dari metilprednisolon
(Baxter, 2010). Jika tidak dapat dihindari, maka meningkatkan dosis kortikosteroid menjadi 2 sampai 3 kali lipat adalah pilihan lain di samping monitoring ketat pada pasien (Tatro, 2008). Kategori moderat selanjutnya adalah kombinasi ampisilin dan gentamisin. Penggunaan kedua obat ini harus diberikan secara terpisah selama terapi kombinasi dan tidak dicampur dalam wadah IV yang sama. Penggunaan kombinasi obat ampisilin dan gentamisin di Rumah Sakit Ananda, Purwokerto diberikan secara terpisah selama terapi kombinasi, sehingga tidak terjadi interaksi farmaseutik yang menyebabkan terurainya gentamisin secara fisikokimia (Almasdy et al., 2013). 
Interaksi obat pada kategori minor secara klinis tidak memberikan manifestasi klinik yang berbahaya jika digunakan, namun tetap perlu dilakukan monitoring pada saat penggunaannya (Barliana et al., 2013). Interaksi obat golongan antibiotik yang terjadi pada kategori minor terjadi pada interaksi antara isoniazid dan metilprednisolon. Penggunaan kedua obat ini secara bersamaan dapat menyebabkan penurunan konsentrasi serum isoniazid, namun hal ini tidak membutuhkan tindakan khusus.

\section{Kesimpulan}

Terdapat interaksi obat antara antibiotik dengan antibiotik maupun antibiotik dengan obat lain pada pasien pediatri di Rumah Sakit Ananda, Purwokerto periode Februari-April 2018. Antibiotik yang berinteraksi antara lain ampisilin-gentamisin, isoniazidparasetamol, rifampisin-parasetamol, isoniazid-metilprednisolon, rifampisinmetilprednisolon. Jenis interaksi obat antara antibiotik dengan antibiotik maupun antibiotik dengan obat lain terjadi pada interaksi farmakokinetik $(54,5 \%)$ dan pada interaksi farmakodinamik $\quad(45,5 \%)$ Tingkat keparahan interaksi obat antara antibiotik dengan antibiotik maupun antibiotik dengan obat lain terjadi pada kategori mayor $(18,2 \%)$, kategori moderat $(72,7 \%)$ dan kategori minor $(9,1 \%)$

\section{Daftar Pustaka}

Aberg, J.A., Lacy, C.F., Amstrong, L.L, Goldman, M.P, Lance, L.L. 2009. Drug Information Handbook. $17^{\text {th }}$ edition. Washington: Lexi-Comp for the American Pharmacists Association.

Almasdy, D., Deswinar, Helen. 2013. Evaluasi penggunaan antibiotika pada suatu rumah sakit pemerintah di Kota Padang. Prosiding Seminar Nasional Perkembangan Terkini Sains Farmasi dan Klinik III. 4-5 Oktober 2013. Universitas Andalas, Kampus Limau Manis, Padang.

Ament, P.W., Bertolino, J.G., Liszewski, J.L. 2000. Clinical pharmacology: clinically significant drug interactions. American Family Physician, 61:1745-1754.

$$
\begin{gathered}
\text { Drug Interactions Checker. } \\
\text { https://www.drugs.com/ } \\
\text { drug_interactions.php. Diakses } \\
\text { pada bulan Februari - April } 2018 .
\end{gathered}
$$

U.S Food and Drug Administration. 2015. The International Commite on Harmonization.

https://www.fda.gov/downloads/ Drugs/NewsEvents/UCM446914.p df. Diakses pada 4 Januari 2018.

Barliana, M.I., Sari, D.R., Faturrahman, M. 2013. Analisis potensi interaksi 
obat dan manifestasi klinik resep anak di Apotek Bandung. Jurnal Farmasi Klinik Indonesia, 2(3):121126.

Baxter, K. 2010. Stockley's Drug Interactions. London: Pharmaceutical Press.

Chelkeba, L., Alemseged, F., Bedada, W. 2013. Assessment of potential drug-drug interactions among outpatients receiving cardiovascular medications at Jimma University specialized hospital. South West Ethiopia, 2(2):144-152.

Farida, Y., Soleqah, A.D. 2016. Identifikasi potensi interaksi obatantibiotik pada peresepan pneumonia. Journal of Pharmaceutical Science and Clinical Research, 01(02):90-101.

Febrianto, A.W., Mukaddas, A. Faustine, I. 2013. Rasionalitas Penggunaan Antibiotik pada Pasien Infeksi Saluran Kemih (ISK) di Instalasi Rawat Inap RSUD Undata Palu Tahun 2012. Natural Science: Journal of Science and Technology, 2(3):20-29.

Farida, Y., Soleqah, A.D. 2016. Identifikasi potensi interaksi obatantibiotik pada peresepan pneumonia. Journal of Pharmaceutical Science and Clinical Research, 01(02):90-101.

Getachew, H., Assen, M., Dula, F., Bhagavathula, A.S. 2016. Potential drug-drug interactions in pediatric wards of Gondar University Hospital, Ethiopia: a cross sectional study. Asian Pacific
Journal of Tropical Biomedicine, 6(6):534-538.

Hartini, S., Pertiwi, P.P. 2015. Efektifitas kompres air hangat terhadap penurunan suhu tubuh anak demam usia 1 - 3 tahun di SMC RS Telogorejo Semarang. Jurnal IImu Keperawatan STIKES Telogorejo Semarang, 2015:1-5.

Juurlink, D.N., Mamdani, M., Kopp, A., Laupacis, A., Redelmeier, D.A. 2003. Drug-drug interaction among elderly patients hospitalized for drug toxicity. JAMA, 289(13):1652-1658.

Lestari, R.A. Hospital Infection Di Ruang Perawatan Bedah RSUD Tenriawaru Kelas B Kabupaten Bone. Skripsi. Fakultas IImu Kesehatan, UIN Alauddin Makassar.

Maharani, P., Astiti, A., Mukaddas, A. Identifikasi drug related problems (DRPs) pada pasien pediatri pneumonia komunitas di Instalasi Rawat Inap RSD Madani Provinsi Sulawesi Tengah. Jurnal Farmasi Galenika, 3(1):57-63.

Ramadhan, N.S., Rasyid, R., Syamsir, E. 2015. Daya hambat ekstrak daun pegagan (Centella asiatica) yang diambil di Batusangkar terhadap pertumbuhan kuman Vibrio cholerae secara in vitro. Jurnal Kesehatan Andalas, 4(1):202-206.

Rambhade, S., Chakarborty, A., Shrivastava, A., Patil, U.K., Rambhadeet, A. 2012. A survey on polypharmacy and use of inappropriate medications. 
Toxicology International, 19(1):68-

73.

Rahayuningsih, N., Mulyadi, Y. 2017. Evaluasi penggunaan antibiotik sefalosporin di ruang perawatan bedah salah satu rumah sakit di Kabupaten Tasikmalaya. Jurnal Kesehatan Bakti Tunas Husada, 17 (1):139-147.

Rikomah, S.E. 2016. Farmasi Klinik. Yogyakarta: Deepublish.

Setiawati, A. 1995. Interaksi obat. Dalam: Ganiswara, S.G. (Ed.) Farmakologi dan Terapi. Edisi 4. Jakarta: Fakultas Kedokteran UI.

Setiawati, A. 2007. Interaksi obat. Dalam: Gunawan, S.G., Setiabudy, R., Nafrialdi, Elysabeth (Eds). Farmakologi dan Terapi. Edisi 5. Jakarta: Departemen Farmakologi dan Terapetik FK UI.

Sinaga, C., Tjitrosantoso, H., Fatimawali. 2017. Evaluasi kerasionalan penggunaan antibiotik pada pasien gagal ginjal di RSUP Prof. Dr. R. D. Kandou Manado. Jurnal IImiah Pharmacon, 6(3):10-19.

Sjahadat, A.G., Muthmainah, S.S. 2013. Analisis interaksi obat pasien rawat inap anak di rumah sakit di Palu. Jurnal Farmasi Klinik Indonesia, 2(4):1-6.

Sukandar, E.Y., Hartini, S. 2012. Evaluasi penggunaan obat tuberkulosis pada pasien rawat inap di ruang perawatan kelas III di salah satu rumah sakit di Bandung. Acta Pharmaceutica Indonesia, XXXVII(4):153-158.

Tatro, D.S. 2008. Drug Interaction Facts 2009: The Authority on Drug Interactions. Saint Louis, Mo.: Wolters Kluwer Health/Facts \& Comparisons.

Tjay, T.H., Rahardja, K. 2015. Obat-obat Penting, Khasiat, Penggunaan dan Efek-Efek Sampingnya. Edisi ketujuh. Jakarta: PT Elex Media Komputindo.

Utami, M.G. 2013. Analisis potensi interaksi obat antidiabetik oral pada pasien di instalasi rawat jalan Askes Rumah Sakit Dokter Soedarso Pontianak Periode Januari-Maret 2013. Skripsi. Program Studi Farmasi, Fakultas Kedokteran, Universitas Tanjungpura Pontianak. 